\title{
Chambers of work- steps in the development of labor law
}

\author{
Ion Țuţuianu PHd, "Vasile Alecsandri” University of Bacău, Romania
}

\begin{abstract}
Social changes that followed the war and perfection state unit generated new and complex problems in all areas. We try to present problems directly aimed at the working class, that is formalized and institutionalized labor, social and economic context of the time. As regards labor law of 1927 rooms and discussions around it, brought the authors to the conclusion that trying to regulate relations between labor and capital and precise directives followed, social reconciliation, abolition of trade union activity, labor movement split and its supervision. Concessions workers were considered only illusory and employers with state dominance. However during 1933/1934, Chambers work activity had a positive role in the field of enforcement of labor law, serving an important role in other institutions and labor organizations, representing a significant step in the development of labor law.
\end{abstract}

\section{Keyword:}

labor law, rooms, development

After completion state ${ }^{1}$ drive new socio-economic framework of the Romanian legal system to require a more developed labor. Industrial progress and the emergence of the International Labour Organisation ${ }^{2}$, acquires new meanings in the political and socio-economic. Postwar period, characterized by revolutionary effervescence, with extensive evidence of labor actions, proved political maturity and the need for new approaches to labor issues and modernizing state The result of this turmoil we find expression in legal formulas governing relations between labor and capital, without harming the essence of the state, bringing the two inputs vigorous intervention by administrative bodies both in production and in the political-social working class. In this context, a new Romanian legislation appear: Board Rooms employment and labor. This responds to the need to resolve legal developed two aspects: on the one hand put on new principles relations between employees and employers, on the other hand was a feature of European rules, since enactment of room to work in France, England Italy takes place at the end of sec. XIX and early XXth century Austria and Yugoslavia

In order to accomplish this goal legislative occurred several political forces of the time.

The first proposal for the founding of labor rooms in Romania, a find made in the Socialist Party's electoral program, presented at Conference 23 to 26 May 1919, who see their role in resolving disagreements between labor and capital ${ }^{3}$.

Advantage of taking power in 1922, the National Liberal Party, seeking to streamline presence on the political scene, by drawing up a comprehensive labor legislation into a single

\footnotetext{
${ }^{1}$ Ștefan Pascu, Făurirea statului național român, 1918,Editura Academiei, București, 1983, vol.,p. 131

${ }^{2}$ Prin Tratatul de la Versailesîn 1919. Vezi și Nicolae Voiculescu, Drept cumunitar al muncii, Editura Rosetti, București, 2005, p. 12.

${ }^{3}$ Vezi Documente din istoria mișcării muncitorești din România, 1916-1921. Editura politică, București, 1966, p. 371.
} 
system by designing and creating work based on the principle rooms equal representation of workers and employers ${ }^{4}$ but have not had the support of workers or employers to legislate. ${ }^{5}$ In June 1925, there is a new attempt of the Ministry of Labour, providing the project besides setting unit labor room (only employees) and regulation at rest Sunday, major project due to opposition industrialists, disappeared on his way to the Senate in Room ${ }^{6}$.

After these unsuccessful attempts, we find a change of strategy adopted by the new Labour Minister Gregory Trancu Iasi, projects or organizations that send professional workers and employers, labor inspectorates, corporations, civil societies and associations, chambers of commerce and industry for review and observations to establish a common vision

The draft labor rooms were representative body care and labor in industry and commerce, with legal personality and their territorial distribution would be made according to the economic importance of each region

But with all successful adoption or not this project legislatv enjoyed a very smooth way, for while the state had given to reducing the conflict between labor and capital, labor organizations is seen as an attempt to liquidate trade unions ${ }^{7}$.

This is all the more as work rooms had always checked by the Ministry of Labour. All he could dissolve Ministry when offenders situation against public order or national security. (Article 42). In addition to close cooperation with the Ministry of Labour, rooms employment must maintain good relations between inputs contribute to a solid organization and training of employees to meet labor market, help organize placement offices, signaling authorities as necessary measures to remove or reduce unemployment crisis.

Contributes to the establishment of cultural institutions for employees in commerce and industry ministry requested priectele opinion on labor issues, carry out investigations in enterprises, to defend and uphold justice, the rights of employees in the event of unpaid wages, unfair dismissal or breach of employment contracts., collaborate with county or municipal authorities and other professional cameras ${ }^{8}$.

Side effects of working class occurred within the People's Assembly held in Anina, Timisoara, Brasov and Ploiesti, who considered setting up cameras work as a burden placed on their shoulders and the principle of parity as a subordinate to the employers. Labour Inspectorate of Arad and General Confederation of Labor, speaks only for workers' representation on these organizations ${ }^{9}$

And factory decides by magazine "UGIR" just cameras workers if the government does not give up on this project ${ }^{10}$

Political opposition rallying to speculate when workers attitudes and hub, Peasants by the voice of RH, Ioanitescu, and liberals by I.Inculeţ the view that achieving social harmony can not be achieved in the same organization encompassing the employer and the salary element only separating them. But, despite the opposition of manifest different categories and classes, rooms employment bill and higher labor council passed through two rooms and was voted in April 1927. However budgetary reasons, the law could not be applied.

Law analysis leads to the conclusion that trying to regulate relations between labor and capital and give a legal basis, followed a few specific objectives: social harmony, the

\footnotetext{
${ }^{4}$ Inițiativa a aparţinut lui Gh.Mârzescu, care propune redactarea unui Cod al muncii cu toată legislația aferentă relațiilor de muncă.

${ }^{5}$ Vezi Universul din 19 martie 1923.

${ }^{6}$ Această încercare a aparținut ministrului Muncii N.D.Chirculescu.; vezi N.D.Chirculescu, P.N.L., șI politica socială , în Revista de studii sociologice și muncitorești, I, 2, sept. oct.1933, p.3

7 Vezi D. Galașescu -Pyk, Munca și democrația în Democrația, XI 3, martie 1923, p. 25

8 . Em.Bold, Gh.Iacob, Contribuții privind studierea și cunoașterea legislației muncii din Romania, în Cercetări istorice, Iași, 1975, p. 223.

${ }^{9}$ I.Bogoly, Manualul Camerii de muncă Brașov, Edit.Gologov, braşov, 1936, p. 5

${ }^{10}$ Socialismul, 20 martie 1927
} 
abolition of trade union activity, blurring the labor movement and its strict supervision. Law displeased both the workers and the employers and the failure was inevitable.

With a budget from employee contributions, without any material aid from the state or employers, lack of autonomy, work rooms became institutions that was hard to find some organs hybrid character, socially useless, unsustainable. ${ }^{11}$

The idea was not abandoned and in 1932, DR Ioanitescu, as labor minister, drafted a new project, eliminating the parity principle is adopted became law on 11 October 1932 and in 1933 work rooms were set up ${ }^{12}$

As a first prerogative prescribed by law for labor rooms, consist of notification higher authorities about the situation of workersand to the officials private and craftsmen. In this context, rooms employment is concerned with improving labor legislation, had the task of making laws and approve such proposals. ${ }^{13}$

Persistent concern in such matters, has often spoken against abusive employers who considered this action to be informed on the situation of workers, considering it biased ${ }^{14}$

All the power of these institutions of social policy was: Labour compliance control, whose prerogative field event was different from one period to another. Thus, in the period 1933 1936, presidents and secretaries involved in monitoring cameras work on the implementation of all labor laws with labor inspectors and singular controls how law enforcement at rest Sunday., Highlighting the positive role of labor room within the scope of labor law. ${ }^{15}$

In the second phase from 1936-1944, the law restricted the power of working room compared to the previous period, meaning that in addition to law enforcement controls at rest Sunday, were only able to request inspectors, organizing controls regarding other labor laws without the participation of any member of the House can work. ${ }^{16}$

In such conditions one of important functions of the Boards of work that should complement the others could be exercised only partially, as a result minimal effects. Activity Report of the working chamber Arad 1936, refer the matter, that the new procedure was cumbersome pit, rooms employment because they could not intervene promptly when abuse occurs. ${ }^{17}$ Following these institutions have expressed on various occasions desire to change restrictive provisions contained in the 1936 Act, to expand their opportunities to exercise control over labor laws. Report of the Union of Chambers of Labour for the year 1938/1939 reaffirmed the need to reorganize labor inspection in the sense of close collaboration with chambers of labor, since the application of labor laws leaves much to be desired and generate more conflicts and discontent muncitoreşti.Ideea is included among the masses and work materials prepared rooms in Iasi, Ploiesti, Bucharest, Craiova, Timisoara. In general we can say that the performance of inspection of the implementation of labor laws by working rooms was reduced in scope, because forms of execution - and therefore effectively limited.

One of the most important powers of the new institutions was the training, area which had a range of powers provided by law or pine organizing training and exercise rules on craftsmanship. Giving these tasks was the natural consequence of the abolition of guilds corporate reorganization trades, responsibilities incumbent by law chambers work to protect and encourage their members work

${ }^{11}$ Gh.Neculcea, Camerele de muncă și Consiliul Superior, în societatea de mîine, IV, 12-13, aprilie 1927, p. 179

${ }^{12}$ Vezi Legea pentru înființarea Camerelor de muncă și Regulamentul lor electoral, Edit.Librăriei Universala, București, 1934.

${ }^{13}$ Buletinul Camerei de muncă Oradea, I, 1, 1934,p.4.

${ }^{14}$ Buletinul UGIR XIII,nr.4/ 1934, p.5 și nr. 10-12/1936, p.11.

${ }^{15}$ Buletinul Camerei de muncă București, IV, 1-6, 1937,p.13.

${ }^{16}$ Legea pentru înființarea Consiliului Superior economic și organizarea camerelor profesionale, din 29 aprilie 1936.

${ }^{17}$ Buletinul Uniunii Camerelor de Muncă,III, 18-24, 1939,p.26. 
Giving these tasks was the natural consequence of the abolition of guilds, corporations, trades reorganization, responsibilities incumbent by law chambers work to protect and encourage their members work.

Therefore, these tasks should be understood in terms of their double character, namely: a) administrative, expressed by organizing professional training and development committees or to exchange cards craftsman, worker, laborer, certificates of apprenticeship, b) the social educational establishment translated into professional training and financial support of workers, artisans, clerks individuals to complete their studies.

Delimitation entail logically and nuanced appreciation of the manner in which labor rooms have fulfilled these duties

They have contributed to unify titles capacity to boost, by combating illegal exercise of professions ${ }^{18}$ At the same time by organizing professional training courses in almost every work meeting rooms, they provided apprentices, workers, craftsmen and even an organized private officials to restore and supplement specific knowledge of their activities. ${ }^{19}$

This activity, although limited in scope, mainly due to financial shortfalls and reduced inspection powers law enforcement work is a real contribution to vocational training and retraining of the categories listed. New institutions exercising a series of tasks aimed at the prevention and settlement of labor conflicts expressed through: registration of contracts of employment and apprenticeship, organizing a conciliation commission, the organization disputed claims service, maintenance spending part of the work of judges. ${ }^{20}$

The effects of this activity has been limited, both because of limited financial resources, but especially because of contradictory and confusing provisions of various labor laws regarding labor disputes and their resolution

Achievements of the labor room should be mentioned: the allocation of funds to encourage and assist deserving disciples, disciples maintenance homes, supporting employment offices, and helping the unemployed, organizing medical offices, canteens, hostels, libraries, organizing exhibitions handicraft products in the country and support the participation of Romanian craftsmen at international exhibitions in Paris ( 1937), Berlin (1938) și New York ( 1939). To determine as accurately place of work room in labor law in the interwar period, the efficiency of their work to be understood in a nuanced depending on a number of factors: business lines, dividing into three distinct sections of new institutions (workers, craftsmen, private officials); attitude of political parties, employers and the working class.

So the new social and political institutions have fulfilled especially those advisory and administrative functions such as expressed by the gathering of information on the employment situation, recording contracts, issuing qualification card. They failed to realize, however, fully designed in the application of labor laws, the application of labor disputes, professional development, social. Is found while carrying out the powers conferred by laws that favored differential and unequal members of the Boards of work sometimes.

Thus the exercise of powers of some with the information, and control used mainly conciliation employees and the professional qualification, almost exclusively, craftsmen.

Taking into account that the last phase of the work-room work after 1938 were particularly concerned qualification, we can conclude that in the years they served mainly the interests of craftsmen. Among the factors that have diminished the role of labor rooms in socioeconomic life, have prevented their mission, first mention limited autonomy and use nejudicioasă low budget so by law ${ }^{21}$. In this context one transcript is enlightening ministry: "Lords of the Boards of work looks to be an institution placed under the control of the ministry. Strict enforcement will follow the law and whenever cameras work will try to

\footnotetext{
${ }^{18}$ Buletinul muncii, XVI, vol.I-II, 1936, p. 67.

${ }^{19}$ Buletinul UCM,III, 18-24, 1939, p. 54, 223.

${ }^{20}$ Contracte de ucenicie înregistrate la camerele de muncă în 1936-1938, Imprimeriile statului, Buc. 1939,p. 202.

${ }^{21}$ Monitorul oficial, nr. 44/3sept. 1936, D.S. șed. 27 martie, p. 1935.
} 
overcome the powers will be brought to reality ". This is compounded by the attitude of employers who, regardless of their form of expression, had a substantial influence on the work of the Boards of work, managed to reduce the opportunities for low and so original and amended by law.

But what has most diminished activity room was politicizing their work, which is the introduction to the governing bodies of these institutions ruling political party agents.

Method was the appointment of interim committees elected boards instead.

In this way, the ruling circles could handle labor rooms, quashing the bud actions had endangered the interests of the bourgeoisie.

However, rooms employment during 1933-1934, had a positive role in law enforcement labor law through their holding an important role in other institutions and organizations working in Romania.

\section{Bibliography}

1. Sanda Ghimpu, Al.Țiclea, Dreptul muncii, București, 1994

2. Nicolae Voiculescu, Drept comunitar al muncii, București, 2005

3. Andrei Popescu, Dreptul internațional al muncii, București, 1998

4. Gh.Filip, Albert Lozeanu, Ștefan Coste, Roxana lazăr, Dreptul muncii, Junimea,Iași, 2008.

5. I.Traian Ștefănescu, Tratat de dreptul muncii, vol, I, Lumina Lex, București, 2003.

6. D.Firoiu, Dreptul muncii, vol.II. Cluj, 1980.

7. S.Beligrădeanu, Legislația muncii comentată, vol.IV, Lumina Lex, București, 1993.

8. S.Ghimpu, I.Tr.Ștefănescu, Dreptul muncii, vol.II, București, 1974.

9. G.Tașcă, Politica sociașă a României, București, 1940.

10. Al Țiclea, Codul muncii comentat, Universul juridic, București, 2011. 